\title{
A multicultural paradise? The cultural factor in Dutch integration policy.
}

Jan Willem Duyvendak*, Trees Pels and Rally Rijkschroeff

Paper presented at the $3^{\text {rd }}$ ECPR Conference - Budapest, 8-10 September 2005

Open Section (31) 17: What the hell happened to the Netherlands? Public culture and minority integration in the country of (in)tolerance

* Jan Willem Duyvendak, University of Amsterdam, Department of Sociology and Anthropology, Oudezijds Achterburgwal 185, 1012 DK, Amsterdam, the Netherlands; emailadres: duyvendak@uva.nl 


\section{Abstract}

This paper closely scrutinizes two assumptions regarding Dutch integration policies: (1) they were a failure on the socio-economic front, and (2) facilitating pluralism was what Dutch cultural integration policy was all about. On the basis of an in-depth study of integration policies over the past thirty years, the authors conclude that both assumptions have to be refuted. That there exists a wider cultural gap between Muslims and natives in the Netherlands than in most other European countries is not due to non-interfering multicultural policies but to the increasingly monocultural nature of native Dutch citizens. This rather homogeneous, progressive nature explains the cultural gap with Muslim inhabitants, who adhere to conservative morals in the Netherlands as they do elsewhere in Europe. 


\section{Introduction}

The issue of multiculturalism, or rather, how much and what kind of cultural differentiation is to be allowed in the public domain, is currently a subject of heated debate in various west European countries. Many of these countries have witnessed the rise of right wing populist parties that consider migrant identities a threat not only to processes of integration but also to national identity (Van Kersbergen \& Krouwel 2003). Whether the prevailing integration policy has stressed accommodating immigrants' cultural or religious identities for any length of time, as in the Netherlands and Great Britain, or favours cultural monism, as in Germany and France, the 'culture' debate is raging everywhere (e.g. Brubaker 2001; Benhabib 2002; Favell 2001; Gutmann 2003; Mendus 2000; Parekh 2000, Joppke 2004). Much of the debate focuses on Islamic minorities, which form the majority of the migrant population in Western Europe. The building of mosques, the use of religious symbols such as the headscarf, the call to prayer, gender inequality, anti-integration pronouncements by ultra-orthodox imams and political extremism inspired by Islam are all popular media subjects (e.g. ; Uitermark, Rossi \& Van Houtum 2005;Verhaar \& Saharso 2004). There is an increasing fear of Islam among citizens of the majority population (EUMC 2002; Scheepers, Gijsberts \& Hello 2002). This also applies to the Netherlands, a country once renowned for its cultural tolerance, where the LPF, an Islamophobic party, came second in the elections of 2002, despite the murder of its leader, Pim Fortuyn.

In this article we deal with the 'retreat of multiculturalism' in the Netherlands, one of the alleged former standard-bearers of this policy in Europe. According to Joppke (2004: 248), the Dutch recently abandoned their pluralistic policy for a policy of civic integration for two major reasons:

- Socio-economic: the Dutch integration policy was incapable of remedying the most pressing problems among immigrants and their offspring - unemployment and economic marginalization.

- Social-cultural: the whole approach of 'emancipating' the designated minorities as groups within their own parallel institutions had detrimental effects, and fuelled segregation and separation from mainstream society.

Dutch pluralist integration policy is thought to have had not only a pernicious effect on the socio-economic integration of migrants but also a negative impact on their socio-cultural integration. In the Dutch debate on 'the multicultural drama', the same doubts regarding the effectiveness of the integration policies led in 2002 to the establishment of a parliamentary committee of inquiry. As requested by this committee, we carried out an evaluation study into the objectives and results of the Dutch integration policy during the period 1970 - 2002 (Rijkschroeff, Duyvendak \& Pels, 2004; Rijkschroeff, Ten Dam, Duyvendak, De Gruijter \& Pels, 2005). 
In this article we first describe the approach used in the research on which this article is based. The following section is dedicated to the empirical data of our evaluation study regarding the assumptions that: 1 ) the Dutch integration policy was a failure on the socio-economic front, and that 2) facilitating pluralism was indeed what Dutch cultural integration policy was all about. The results of our evaluation study refute both assumptions. In the second part of the article we elaborate on an alternative explanation for the move to civic integration and even assimilation in the Netherlands: the intolerance of pluralism in the Dutch cultural mainstream. The 'progressive' liberal cultural consensus that characterises the Dutch cultural mainstream may have contributed as much or even more to the current intolerance of cultural difference than the alleged failure of Dutch integration policy.

\section{Method}

The following research questions were investigated in our evaluation study:

1. What were the objectives of Dutch integration policy over the past thirty years?

2. How coherent and consistent have the socio-economic and social-cultural aspects of integration policy been?

3. To what extent have the objectives of integration policy been achieved?

A historical study of original sources was conducted in order to examine the policy of the Dutch government on migrants and minorities over the past thirty years (Research Question 1). To this end, we analysed all relevant recommendations, memoranda and Dutch parliamentary debates. We mapped out the objectives and the changes in the objectives of integration policy and drew up a list of the policy measures connected to these objectives on the basis of the policy documents. Two research approaches were followed when evaluating the integration policy of the Dutch government and the outcomes (Research Question 2). We first summarized the internal and external effectiveness of the policy measures adopted on the basis of available evaluations; the extent to which the policy objectives have been achieved followed, with reference to empirical data. A significant factor in this second line of approach was the various systems that have been established in the Netherlands since the mid-1980s for monitoring the socio-economic position of the target groups of the Dutch integration policy (see Guiradaudon, Phalet \& Ter Wal, 2005). The results of this empirical analysis and of the effectiveness studies were subsequently used to review the success or failure of the Dutch integration policy and its constituent parts (Research Question 3). 


\section{Dutch integration policy: success or failure?}

Commissioned by the parliamentary committee of inquiry, the authors conducted an extensive study into the objectives and results of the integration policy in the Netherlands between 1970 and 2002 (Rijkschroeff et al. 2004). The term 'integration policy' is used here in a neutral sense to refer to the measures taken over the years by the government vis à vis (categories of) migrants and minorities residing in the Netherlands. Actually, the heading 'integration policy' only came into vogue in the 1990s, and referred to individuals' participation in mainstream society and institutions. Prior to that, the terms 'categorical policy' (during the 1970s) and 'minorities policy' (during the 1980s) were used.

The previous history of the Dutch integration policy lies in the recruitment of guest workers during the 1950s and 1960s and in immigration from the (former) colonies, whereby it was assumed that most migrants would stay only temporarily in the country. The 1970s also saw the start of 'follow-up migration', i.e. partners, children and other family members. Nevertheless, it was, at this time, still assumed that these people's stay would only be relatively short-lived. For this reason, the policy was categorical and focused on maintaining group cohesion with, on the periphery, some attention for integration in society. Policy in the 1970s focused on managing labour migration, encouraging a return to the country of origin, and on regulating family and marriage migration.

Assumptions about the temporary nature of the migrants' stay gradually came to be abandoned in the 1980s. This was the era of the minorities policy. Groups of migrants, who combined 'being different' with a low social position, were deemed to be the target groups of the new minorities policy. The minorities policy had two tracks, as expressed in the slogan 'integration while maintaining one's identity', with the twin focus:

- the socio-economic front: combating social deprivation (particularly in the fields of education, the labour market and housing), partly by strengthening the legal position and by opposing unequal treatment, prejudice and discrimination;

- the socio-cultural front: creating the space for the preservation of 'one's own' culture, religion and language, for example by supporting self-organisations and developing a consultative structure.

The 1990s heralded the arrival of a new period, the period of integration policy. The new politics was inspired above all by the persistent educational deprivation of migrants compared with their counterparts of the majority population, together with an increased demand for more highly-educated people on the labour market and a diminishing demand for less highly-educated people (with the concomitant relatively higher unemployment levels among migrants). The integration policy focused on fostering increased participation in education and on the labour market. The emphasis shifted to the socio-economic 
integration of the individual. Attention for collective emancipation through cultural distinctiveness faded into the background.

The mid-1990s saw the emergence of citizenship policy, characterised by a special emphasis on the individual citizen, with his responsibility, rights and duties. The institutionalisation of ethnic diversity was abandoned as a policy objective, and came to be considered as falling within the responsibility of ethnic groups themselves. What did remain was attention for improving the accessibility of mainstream facilities, for developing the social and cultural capital of migrants to further their socio-economic participation and for stimulating interethnic contact.

We conclude that there was considerable consistency in the government policy as far as the socio-economic position of migrants was concerned. Joppke's claim that multiculturalism policies have taken attention away from socio-economic inequities has certainly not been confirmed. Proportionality in the socio-economic position of newcomers was the undisputed objective from the start. The policy merely changed in that, from the late 1980s onwards, this objective was more finely tuned as a result of the continued deprivation in the socioeconomic position of migrants. The objective was to eliminate deprivation in education and on the labour market. Taking all the results into account, we conclude in our evaluation study that some of the most important objectives formulated at that time were achieved. Reducing educational deprivation was particularly successful (see also Rijkschroef et al. 2005), whereas the objective of proportionality in matters of work and income was less of a success. Many objectives in housing matters were attained, and the housing situation of migrants saw considerable improvement. Following on from this, the Parliamentary Committee of Inquiry (2004) came to the conclusion that many migrants were either fully or partially integrated. The popular belief that socio-economic integration had failed was not corroborated by the facts.

The policy that focused on the socio-cultural position was, in the periods under review, characterised by far more variety than suggested by Joppke in his account of Dutch multiculturalism. In the 1970s there was no specific policy on this particular point, and the central tenet was on the 'guest workers' maintaining their identity with a view to their eventual return 'home'. In the early 1980 s, policy tended to concentrate on group cohesion and identity maintenance. These objectives were considered to be valuable in themselves, and emancipation in one's own circle was also considered to be conducive to strengthening the position of minorities in society and to improving interethnic relations. Already in the mid-1980s, however, the objectives of identity maintenance and group emancipation faded into the background.

Central government's socio-cultural integration policy manifested little consistency. It developed from being a categorical approach focused on group emancipation to an approach in which individual integration took centre stage. Recently, objectives have 
been set that involve migrants adjusting to 'Dutch' norms and values in order to avert the impending danger of insufficient cohesion in society.

The many changes and recent toughening up of the socio-cultural objectives would seem to indicate an element of disagreement on what they should be. Whereas today many of the Dutch majority population support the idea of migrants adopting 'Dutch' norms and values, the migrants themselves aspire to a combination of independent cultural development with adjustment, where necessary, for socio-economic integration purposes (Phalet, Van Lotringen \& Entzinger 2000). The changes in policy actually make it rather difficult to assess the extent to which the socio-cultural policy objectives have been achieved: compared with what, today or the past?

There is little support in this history for the idea, as propounded by Joppke and others (for instance Koopmans et al. $2000 \& 2005$ ) that the attention for a categorical approach focused on group emancipation would seem to have obstructed an effective socioeconomic policy. Little appreciation remained for pluralism in government policy in the last fifteen years. An explanation for the postulated socio-economic deprivation of migrants in terms of pluralist socio-cultural policy is not, to put it mildly, probable.

It seems that over time, and mainly as a result of the variation in the socio-cultural objectives, there were significant shifts in the policy visions regarding the relationship between the socio-economic position of minorities on the one hand and their socio-cultural position on the other. These shifts are presented diagrammatically in Figure 1, which shows that cultural distinctiveness is perceived increasingly often as a problem.

Figure 1: Policy views on the connection between socio-cultural position and socio-economic position in the course of time

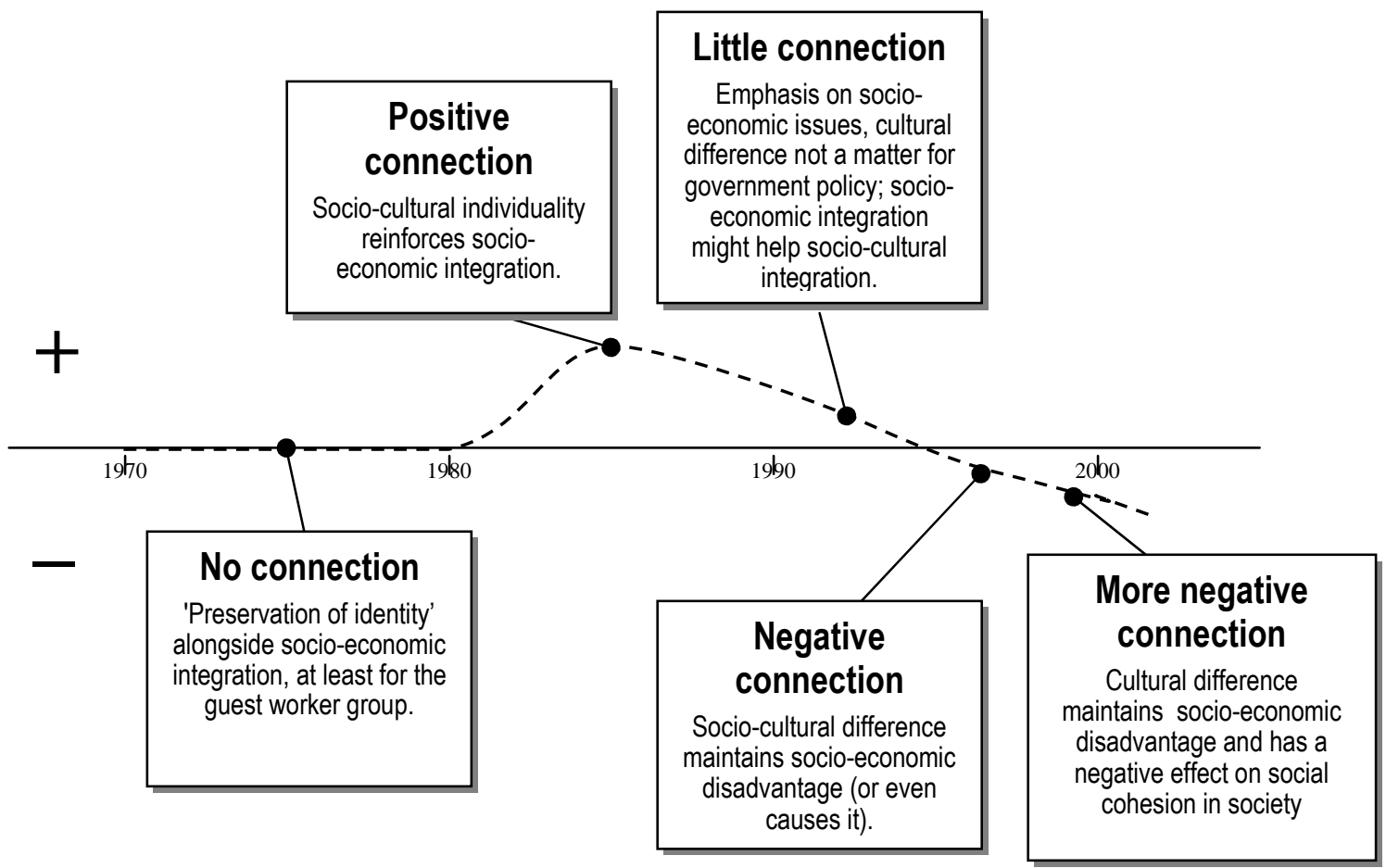


The results of the evaluation study of Dutch integration policies developed by the Dutch Parliament have denounced the claim of negative integration outcomes, by pointing to the progress made in the important socio-economic domains of education and housing.

Furthermore, it has refuted the very assumption that the Dutch integration policy was unequivocally characterised by pluralism. On closer scrutiny, this assumption has turned out to be ripe for revision, one reason being that the socio-cultural integration policy has been particularly inconsistent. It changed during the 1980s from a categorical approach focused on group emancipation to one in which the individual and individual integration were put centre stage.

In so far as migrant organisations with a religious basis were eligible for facilities, it had nothing whatsoever to do with integration policy (Duyvendak et al. 2004). It is important in the specific Dutch context to make a clear distinction between integration policy (including the policy relating to migrant self-organisations) on the one hand, and the legal right to organise oneself on the basis of religious identity (the heritage of the Dutch pillar system) offered to all, and so also to newcomers, on the other. Where the legal fall-out of pillarisation $^{i i}$ facilitates the founding of organisations on a religious basis (schools can be founded on, for example, religious principles, but they are not eligible for subsidies on the basis of ethnicity or nationality), then self-organisations with a religious basis were not and are not, from the integration policy, eligible for subsidies (Rath, Penninx Groenendijk \& Meijer 1999). Researchers who mistake the pillarised institutional heritage for policies intentionally developed by new generations of politicians, will never give a good picture of the actual situation in the Netherlands, a country that changed so rapidly in and after the 1960s.

That Islamic self-organisations developed, was not due to the support of Dutch policy makers (nor to a lack of it). As Koopmans acknowledges, the influence of governments on religious self-organisation is limited: 'The Muslim identity is especially resistant against state attempts to channel migrant identities' (2002: 13). Just as in France, a country that attaches great value to cultural monism, Islamic self-organisations in the Netherlands developed contrary to the dominant political philosophies. The Dutch government was indeed not willing to finance religious self-organisations of migrants (apart from, since 1983, activities of an explicitly non-religious but socio-cultural nature). In the first place this had to do with the diminishing importance of religious organisations in a depillarising country and the acknowledged separation of church and state. In the second place there was an idea that religious organisations were perhaps the least well equipped to form a 'bridge' to society. Religious organisations were assumed, after all, to keep people in isolation. In these kinds of organisations there are some who do indeed also acquire social capital (Fennema et al. 2000), but they are mainly deployed as a tool for keeping an eye on one's own supporters, according to the dominant idea (Sunier 2000). 
That religious self-organisations have developed does not fit in very well with Dutch integration policy (Feirabend \& Rath 1996). However, it does mesh with the development that Koopmans and Statham (2000) also encountered in countries where even much less room is given to religious (self)organisations: newcomers from Muslim countries organise themselves very much on the basis of Islam, irrespective of opportunities offered by national policies. The integration policy is apparently not (particularly) relevant for the development of Islamic identity, neither in the Netherlands, nor elsewhere.

\section{Intolerance of pluralism in the cultural mainstream}

The image of the Netherlands as a liberal, heterogeneous country that has been confronted with the limits of its own tolerance is just partly correct. As argued above, though the Dutch tradition of pillarisation gave some leeway for religious (Islamic) institutionalisation, integration policies at large never emphasised religious identities. Moreover, the maintenance of whatever kind of 'original' identities was already disregarded in the late 1980s. That 'culture' is given so much attention today is not because of a Dutch appreciation of 'culturally pluriform policies' but rather precisely the opposite: the Netherlands has rapidly become culturally homogeneous and more uniform - as far as the majority population is concerned. Whereas in many other countries there is serious division of the majority population in public and political opinion on matters of gender, and definitely on matters of sexuality, almost the entire political spectrum of the majority population in the Netherlands supports progressive values.

Research data form the Euro-barometer, European Social Survey, European Values Study, International Social Survey Program, Continuous Tracking Survey, recapitulated in SCP (1998), Uiterhoeve (2000), Arts, Hagenaars \& Halman (2003), Duyvendak (2004), and Halman, Luijkx, and Van Zundert (2005) show that, of all European citizens, the Dutch majority population

- adheres the most to the belief that divorce is acceptable and homosexuality is nothing out of the ordinary;

- values the most the freedom of religion and conscience, and the right to legal protection against discrimination;

- agrees the least with the position that 'women have to have children to be happy', 'that a child should respect its parents' or that 'we would be better off were we to return to a traditional way of life';

- $\quad$ is the least convinced of the desirability of a strong leader.

Less than other countries, the Netherlands seems to have a value gap between more highly educated people and less highly educated people, where normally the former cling to more culturally progressive values, and the latter to more conservative values; at any rate, this conservative position is not politically articulated. 
Whereas in France the importance of shared republican values is propagated from the fear that the already polarised society of the majority population will fall further apart as a result of immigration ${ }^{\mathrm{iii}}$, it would appear that the assimilation mentality in the Netherlands is becoming more dominant as a result of the relatively strong consensus of the majority population. In this respect, the Netherlands is very similar to Denmark and Sweden ${ }^{\text {iv }}$, where there is also a clearly 'enlightened' moral majority. In both Sweden and Denmark, the 'progressive' consensus asks for a policy that is more focused on assimilation of those who are assumed to fall outside that consensus. That progressive countries pursue a demanding policy when it comes to newcomers and their children is definitely food for thought. It goes to show that, when it comes down to values, a 'tolerant' country does not necessarily have to esteem diversity.

The Dutch majority population does not stand out for the value it attaches to cultural pluriformity, or so it would appear from the prevailing evidence. This is due to the cultural homogenisation that has taken place in recent decades. The majority have developed remarkably uniform, progressive ideals. Since Dutch citizens of the majority population differ so little from one another, it would seem that Dutch society is losing its ability to cope with cultural differences. A distinct group (e.g. a denominational school, an ethnic sports club or a migrant student association) is, for some politicians, political commentators and scientists, akin to apartheid.

Whereas Joppke and Koopmans depict the Netherlands as a country that values pluralist concepts of citizenship, it is the exact opposite that has occurred: since the 1990s, the Dutch are becoming less willing to make room for cultural differences. In fact, they are very concerned about the pluralist institutional framework that still exists as a consequence of the era of pillarisation; therefore a majority of the native Dutch want to amend the constitutional law in order to prevent the spread of Muslim schools. Where the history of pillarisation initially appeared to accommodate forms of pluralism, a homogenising tendency set in. Since this homogenisation is based on a set of rather progressive values, the value gap within particular Muslim migrants is big - bigger than in other countries where the majority culture is less progressive.

\section{Conclusion}

Is there a relationship between this relatively like-minded, progressive value orientation in the Netherlands and the integration of minorities? The results of a research into opinions (Dagevos, Gijsberts \& Van Praag, 2003) do indeed indicate a certain gap between Muslim groups and the majority population in the Netherlands, although the support of so-called 'western values' is increasing among Dutch migrants. Nevertheless, the value gap in the 
Netherlands is greater than in other countries. Research by Demant (2005), for instance, shows that the distance in value orientations between the majority population and migrants in Germany is less than that between the majority population and migrants in the Netherlands. As far as values are concerned, Dutch migrants differ much less from the majority population in Germany than from the majority population in the Netherlands in, for example, their views on community spirit, (equality in) gender roles and sexuality. Joppke is right to state that culture does matter. Cultural difference or separateness plays a problematic role in the integration process of migrants. This is not because there is a direct causal link between the Dutch integration policy and its supposed esteem for cultural or religious differences on the one hand and the low levels of socioeconomic achievement of the minority groups on the other hand. But, the other way round, because the majority population is coming to see the cultural difference as more in terms of a problem, which, for instance, does little to enhance the openness of Dutch institutions to migrants (e.g. Pels 2004a).

Due regard for the peculiar nature of the unanimous and progressive nature of the majority population in the Netherlands is required. This is the paradox of recent years: the Dutch majority population deploy their widely shared progressive values to stigmatise and exclude Islamic migrants (e.g. Harchaoui \& Huinders 2003). This leads to exactly the opposite of what is desirable: it plays into the hands of conservative forces, and liberal Muslims are left with few options. Instead, we think we should challenge and encourage migrants to emancipate further - something that the women and girls involved are already doing (Pels 2004b).

We have argued that a 'progressive' liberal cultural consensus that characterises the Dutch cultural mainstream may have contributed as much or even more to the current intolerance of cultural difference than Dutch integration policy. Dutch migrants may have less of a problem with over-the-top political multiculturalism than with increasing monoculturalism in the host society. 


\section{References}

Arts, W., Hagenmaars, J. \& Halman, L. (eds) (2003). The cultural diversity of European unity. Findings, explanations and reflections from the European values study. Leiden: Brill Academic Publishers.

Benhabib, S. (2002) The claims of culture. Equality and diversity in the global area. Princeton/Oxford: Princeton University Press.

Brubaker, R. (2001) 'The return of assimilation? Changing perspectives on immigration and its sequels in France, Germany, and the United States', Ethnic and Racial Studies, 24 (4): $531-548$.

Dagevos, J., Gijsberts, M., and Praag, C. van (2003) Rapportage minderheden 2003. [Report on minorities 2003] . Den Haag: Sociaal en Cultureel Planbureau.

Demant, F. (2005) 'Meer aanpassing dan inpassing. Over de culturele integratie van migranten in Nederland en Duitsland. [More adaptation than integration. The cultural integration of minorities in the Netherlands and Germany], Migrantenstudies, 21 (2): 70 86.

Duyvendak, J.W. (2004) Een eensgezinde en vooruitstrevende natie. [A united, progressive nation]. Amsterdam: Vossiuspers UvA.

Duyvendak, J.W., Rijkschroeff, R., Gruijter, M. de, Daal, H.J. van, \& Weijers, G. (2004) 'Zelforganisaties van migranten' [Selforganisations of Migrants], Aanvullend bronnenonderzoek Verwey-Jonker Instituut, [Additional historical study of original sources on integration policy] T.K. 28689, 12 (2003-2004): 108-163. Den Haag: Sdu.

EUMC (2002) EUMC Report on Islamophobia after September 11. Vienna: EUMC.

Ester, P., Halman, L. \& de Moor, R. (1993) The individualizing society. Tilburg: Tilburg University Press.

Favell, A. (2001) Philosophies of integration: Immigration and the idea of citizenship in France and Britain. Hampshire/New York: Palgrave McMillan.

Feirabend, J., \& Rath, J. (1996) 'Making a Place for Islam in Politics: Local Authorities Dealing with Islamic Associations' in: Shaid W.A.R. and Koningsveld P.S. van (eds) Muslims 
in the margin: Political responses to the presence of Islam in Western Europe. Kampen: Kok Pharos.

Fennema, M., Tillie, J., Heelsum, A. van, Berger, M. \& Wolff, R. (2000) Sociaal kapitaal en politieke participatie van minderheden. [Social capital and political participation of minorities] Amsterdam: IMES.

Guiradaudon, V. Phalet, K. \& Ter Wal, J. (2005) Monitoring ethnic minorities in the Netherlands, International Social Science Journal, 57: 75-87.

Gutmann, A. (2003) Identity in democracy. Princeton and Oxford: Princeton University Press.

Halman, L., Luijkx, R. \& van Zundert, M. (2005), Atlas of European Values. Tilburg: Brill.

Hammarström, G. (1993) 'Värdeförändring och kontinuitet i tre generationer.' Change or continuity in three generations], Studia Sociologica Upsaliensia 37: 156-171.

Harchaoui, S., \& Huinder, C. (eds) (2003) Stigma: Marokkaan! Over afstoten en insluiten van een ingebeelde bevolkingsgroep [Stigma Moroccan! Excluding and including imaginary communities]. Utrecht: FORUM.

Joppke, C. (2004) 'The retreat of multiculturalism in the liberal state: theory and policy', The British Journal of Sociology 55(2): 237-257.

Phalet, K., van Lotringen, C. \& Entzinger. H., (2000) Islam in de multiculturele samenleving. Opvattingen van jongeren in Rotterdam [Islam in the multicultural society. The opinions of young people in Rotterdam], Utrecht: Utrecht University.

Koopmans, R. (2002) Migrant claim-making between transnationalism and national citizenship. Paper for the conference 'Ethno-Religious Cultures, Identities and Political Philosophies', Amsterdam 2-5 July 2002.

Koopmans, R. and Statham, P. (2000) 'Migration and ethnic relations as a field of political contention: An opportunity structure approach' in: Koopmans R. and Statham P. (eds) Challenging immigration and ethnic relations politics: Comparative European perspectives. Oxford/New York: Oxford University Press, 13-56.

Koopmans, R., Statham, P., Giugni, M., and Passy, F. (2005) Contested citizenship: Political contention over migration and ethnic relations in Western Europe. Forthcoming. 
Kriesi, H., Koopmans, R., Duyvendak, J.W., Giugni, M. (1995), New Social Movements in Western Europe. A comparative analysis. Minneapolis: University of Minnesota Press.

Mendus, S. (2000) 'Pluralism and Scepticism in a Disenchanted World' in Bagramian, M. and Ingram A. (eds) The philosophy and politics of diversity. London/New York: Routledge, 44-60.

Parekh Report (2000) The future of multi-ethnic Britain: Report of the commission on the future of multi-ethnic Britain, established by the Runnymede Trust and chaired by Bhikhu Parekh. London: Profile Books.

Pels, T. (2004a) 'Zorg voor het allochtone gezin' [Care for the family of minorities], Tijdschrift voor de Sociale Sector, 5(3): 26-33.

Pels, T. (2004b) Emancipatie en Gezin. [Emancipation and family]. Den Haag: Nederlandse Gezinsraad.

Rath, J., Penninx R. Groenendijk, K., and Meijer, A. (1999) The politics of recognizing religious diversity in Europe. Netherlands Journal of Social Sciences, 35, 53-67.

Rijkschroeff, R., Duyvendak, J.W., and Pels, T. (2004) Bronnenonderzoek Integratiebeleid. [Historical study of original sources on integration policy]. Den Haag: SDU.

Rijkschroeff, R., Dam, G. ten, Duyvendak, J.W., Gruijter, M., \& Pels, T. (2005) Education policy on migrants and minorities in the Netherlands. Journal of Education Policy, 20(4), 417-435.

Scheepers, P., Gijsberts, M., and Hello, E. (2002) 'Religiosity and prejudice against ethnic minorities in Europe', Review of Religious Research, 43(3): 242-265.

Sociaal en Cultureel Planbureau SCP (1998) 25 Jaar sociale en culturele veranderingen. [25 years social and cultural changes]. Rijswijk: SCP.

Sunier, T. (2000) 'Moslims in de Nederlandse politieke arena' [Muslims in the Dutch political arena] in: Sunier, T., Duyvendak, J.W., Saharso, S. and Steijlen, F. (eds) Emancipatie en subcultuur: Sociale bewegingen in België en Nederland. Amsterdam: Instituut voor Publiek en Politiek, 138-157.

The Parliamentary Committee of Inquiry (2004) Bruggen bouwen. [Building Bridges], T.K. 28689, 11 (2003-2004) Den Haag: Sdu. 
Uitterhoeve, W. (2000) Nederland en de anderen. Europese vergelijkingen uit het Sociaal en Cultureel rapport 2000. [The Netherlands and other European countries] Nijmegen: SUN

Uitermark, J., Rossi, U and van Houtum, H. (2005) Reinventing multiculturalism: urban citizenship and the negotiation of ethnic diversity in Amsterdam. International Journal Urban and Regional Research 29 (3), Forthcoming.

Van Kersbergen, K., \& Krouwel, A. (2003) 'De buitenlanderskwestie in de politiek in Europa' [The issue of foreigners in European politics]. in: Pellikaan, H. and Trappenburg, M.J. (eds) Politiek in de multiculturele samenleving. Beleid en Maatschappij jaarboek 2003. Amsterdam: Boom, 188-217.

Verhaar, O., and Saharso, S. (2004) 'The weight of context. Headscarves in Holland' Ethical theory and moral practice, 7(2): 179-195.

\footnotetext{
i 'The multicultural drama' is the title of an article by Paul Scheffer that appeared in one of the national newspapers in 2000. See also: Interview with Paul Scheffer, BBC Monitoring International Reports, 4 May 2002.

${ }^{\text {ii }}$ Pillarisation is a differentiation within society whereby the population is divided into ideologically based social segments each with its own schools, societies, political parties, broadcasting organisations, newspapers, hospitals etc. It is a vertical differentiation running through all the social classes (horizontal stratification). During the first half of the 20th century, Dutch society became divided into a Roman Catholic 'pillar', a Protestant 'pillar', which was further divided internally, and a neutral 'pillar'.

iii French society has pacified traditional lines of conflict much less than for example the Netherlands, Germany or Switzerland (see Kriesi et al., 1995).

${ }^{\text {iv }}$ See, among other things, data from The Individualizing Society (Ester, Halman \& De Moor, 1993), in which Sweden scores highly both on a number of libertarian variables (e.g. a high degree of very limited religious affiliation, acceptance of homosexuality and the value of autonomy at work) and also here, at the same time, a (average) decrease in tolerance for ethnic minorities. On the relative homogeneity of Sweden, see G. Hammarström (1993: 156-171).
} 